\title{
Effects of heat stress on some blood parameters and egg production of Shika Brown layer chickens transported by road
}

\author{
Joachim J Ajakaiye ${ }^{1}$ Joseph O Ayo ${ }^{2}$ and Sunday A Ojo². \\ ${ }^{1}$ College of Agriculture and Animal Science, Ahmadu Bello University, Kaduna, Nigeria. \\ 2 Faculty of Veterinary Medicine, Ahmadu Bello University, Zaria, Nigeria.
}

\begin{abstract}
The effects of vitamins $\mathrm{C}$ and $\mathrm{E}$ on layer chickens transported by road for $6 \mathrm{~h}$ during the hot dry season were investigated. Two experimental groups consisting of thirty Shika Brown layers were separately administered vitamins $\mathrm{C}$ and $\mathrm{E}$ orally just before transportation, while another 30 layers, which were only given sterile water, served as control. Blood samples analyzed before and after transportation in the control layers showed a decrease $(\mathrm{p}<0.05)$ in total white blood cell, $(\mathrm{p}<0.01)$ lymphocyte and monocyte values, and a significant $(\mathrm{p}<0.05)$ and $(p<0.001)$ increase in the values of eosinophils and heterophils post-transportation, respectively. In the experimental groups, post-transportation values of total white blood cells, eosinophils and monocytes were not different ( $p>0.05$ ) from those obtained before transportation. Heterophil/lymphocyte values were highest in the control group. The result showed that transportation was stressful for the control layers. Post-transportation egg production was not significantly $(\mathrm{p}>0.05)$ different in the vitamin $\mathrm{E}$ treated group, but values recorded for the vitamin $\mathrm{C}$ and control groups were significantly $(\mathrm{p}<0.05)$ and $(\mathrm{p}<0.001)$ reduced compared to pre-transportation. In conclusion, vitamins $\mathrm{C}$ and $\mathrm{E}$ administration ameliorated the adverse effect of road transportation stress during the hot dry season.
\end{abstract}

Key terms: Egg production, heat and transport stress, layer chickens, leukocyte profile, vitamins C and E.

\section{INTRODUCTION}

Poultry production has been reported to be the fastest growing in the livestock industry, and more particularly in tropical and sub-tropical regions of the world (Daghir, 2009; Holik, 2009). The establishment of poultry farms in new areas means that live birds of all ages have to be transported by road, across different ecological zones throughout the year. Northern Nigeria is characterized by high air temperatures and high humidity during the hot dry season, with little or no water supply to the animals, which aggravates transport stress (Ayo and Oladele, 1996).

Many elements of the transport process can be harmful to the birds (Knowles and Brown, 1990; Nicol and Saville-Weeks, 1993). These includes handling by humans, air temperature changes, high ambient temperature (AT) and relative humidity $(\mathrm{RH})$, removal of food and water, novelty, confinement, noise, motion, micro-thermal core within the vehicle and the use of inappropriate vehicles (Mitchell and Kettlewell, 1998; Bedonova et al., 2006; Vecerek et al., 2006). The adverse effects of these factors and their combinations may range from mild discomfort and aversion to death. Indeed, studies in the U.K. have indicated that up to $40 \%$ of "dead on arrivals" (DOA) are attributable to "transport stress" (Bayliss and Hinton, 1990) and that mortality increases with journey length (Warriss et al., 1990). Thus, transportation of livestock is a complex multi-factorial and traumatic event (Anokhin et al., 1991; Elrom, 2000). Among these elements, exposure to high AT and $\mathrm{RH}$ has been documented to be a major threat to animal welfare during transport, especially during the hot dry summer months (Hartung, 2003). These factors acting concurrently on transported animals impair normal body functions, leading to increased morbidity and mortality, poor meat quality and decreased productivity (Fazio and Ferlazzo, 2003; Fallenberg and Speisky, 2006; Franco-Jimenez and Beck, 2007; Rozenboim et al., 2007). It has been observed that temperature and moisture of air are two major environmental factors controlling the heat stress of livestock (Bouraoui et al., 2002; St-Pierre et al., 2003). Heat stress to different extents adversely affects egg size, laying percentage, mortality, body weight gain and egg shell durability (Sterling et al., 2003; 
Lin et al., 2004; Franco-Jimenez and Beck, 2007). The combination of high AT and $\mathrm{RH}$ provokes heat stress and the excessive generation of reactive oxygen species (ROS) or free radicals (FR) as a result of increased metabolism in birds (Ramnath et al., 2008). Normally, non-enzymatic antioxidants, such as vitamin $\mathrm{C}$, produced in the bird's kidneys, are involved in the elimination of excess FR or ROS from the body, but under praxis condition, they are either exhausted or overwhelmed; thus, exposing cells to their harmful effects (Maurice et al., 2002). ROS induce oxidative damage of macromolecules, cells and tissues (Altan et al., 2003) that consequently leads to increased morbidity and mortality rates, with substantial economic losses (St-Pierre et al., 2003). It is well documented that changes in hematological values of the heterophil/ lymphocyte ratio $(\mathrm{H} / \mathrm{L})$ is a good indicator of stress (Altan et al., 2000; Huff et al., 2005). Several researchers have suggested various ways of ameliorating the deleterious effects of heat stress acting on birds during transportation, such as administering tranquilizers (aminazine) (Anokhin et al., 1991), and nutritional manipulations through the use of electrolytes (minerals, oils and vitamins) (Holik, 2009). Unfortunately, drug administration in transported food animals increases the risk of consumption of meat with drug residues. The use of vitamins $\mathrm{C}$ and $\mathrm{E}$ as antioxidants in combating heat stress has been documented in Japanese quails (Sahin et al., 2002; Sahin et al., 2003a,b; Ciftci et al., 2005) and in pullets (Sinkalu and Ayo, 2008). However, there is paucity of information on the physiology of transportation on the hybrid Shika Brown layer (SBL), which is indigenous to the Northern Guinea Savannah zone of Nigeria. Therefore, the aims of this study were to establish the effects of dietary supplementation of vitamins $\mathrm{C}$ and $\mathrm{E}$ in this breed of birds transported at high ambient temperatures and to determine their possible ameliorative effects on blood profile and egg production.

\section{MATERIALS AND METHODS}

\section{Experimental site and meteorological data}

The study was conducted at the College of Agriculture and Animal Science, Ahmadu Bello University, Mando, Kaduna ( $11^{\circ} 10^{\prime} \mathrm{N}, 07^{\circ} 38^{\prime} \mathrm{E}$ ), in the Northern Guinea Savannah zone of Nigeria. Data of precipitation and wind direction were collated from the Meteorological Unit of the Institute for Agricultural Research, Ahmadu Bello University, Samaru, Zaria, Nigeria. The AT and RH inside and outside the pen were recorded daily and for three days before and after the journey period at
07:00, 14:00 and 18:00 h, respectively. A standard ambient thermometer for AT and wet and dry-bulb hygrometer for $\mathrm{RH}$ were used. The wet and dry bulb values were recorded, and $\mathrm{RH}$ calculated using the depression factor as indicated in the manufacturer's manual. Both instruments, from Cocet, China, were obtained from a commercial medical equipment sales outlet in Kaduna.

\section{Management of birds and Experimental design}

Ninety apparently healthy (22 weeks of age; Shika Brown) layer chickens and weighing $1.1 \pm 0.0 \mathrm{Kg}$ were randomly divided into three replicate groups (cells) within each of three treatment groups (pens). For the purpose of homogeneity, each pen containing a particular treatment group was partitioned into three equal cells by $5 \mathrm{~m}$ plywood, so that each replicate cell contained 10 birds at a stocking rate of $0.373 \mathrm{~m}^{2} /$ bird (Koelkebeck and Cain, 1984) throughout the study period. All birds were fed a basal layer diet and water was given ad libitum. All necessary medications were administered to the birds. One week to the commencement of the experiment, deep-body temperatures of each bird was recorded daily using a digital thermometer (accuracy $\pm 0.1^{\circ} \mathrm{C}$ ) inserted $5 \mathrm{~cm}$ into the wall of the rectum to ascertain their health status. The birds were also accustomed to the experimental procedures. Food and water were withdrawn just before the journey. On the experimental day and just before loading into the vehicle, the first group was orally administered vitamin C at a dosage of $200 \mathrm{mg} / \mathrm{kg}$ body weight dissolved in $5 \mathrm{ml}$ of sterile water $\mathrm{w} / \mathrm{v}$, while the second group was orally administered vitamin $\mathrm{E}$ at a dosage of $200 \mathrm{mg} / \mathrm{kg}$ body weight dissolved in $5 \mathrm{ml}$ edible vegetable oil $\mathrm{w} / \mathrm{v}$ and the last group was administered only $5 \mathrm{ml}$ sterile water (control) v/v. Subsequently, the birds were transported by road for $6 \mathrm{~h}$ duration. After the journey, the birds were returned to the same pen and kept under the same conditions and fed, as was done before transportation.

\section{Arrangement of birds, vehicle design and journey time}

The birds were easily caught by experts and feather tagged by group. Thereafter, all groups were uniformly inter-mixed and loaded into nine standard crates at a stocking density of $0.0350 \mathrm{~m}^{2} /$ bird (Delezie et al., 2007). In order to maintain the homogeneous distribution of environment and "thermal core" load within the vehicle, the crates were arranged in groups of three from the front to the rear part of the vehicle. The vehicle used for the journey was a customary 18-seater Toyota Hi- 
ace bus that had glass louvers for regulating air movement inside the bus. The top roof was made up of a metal iron from outside and a stock-pile of heat-absorbable foam materials, covered with thick polythene strap from inside. The floor was made-up of metal, and it was covered with $5 \mathrm{~cm}$ wood shavings. The vehicles traveled on a tarred road for a period of $6 \mathrm{~h}$ at a speed of $50 \mathrm{~km} / \mathrm{h}$. Meteorological data inside and outside the vehicle were recorded during the journey using a standard ambient thermometer for AT and a wet and dry-bulb hygrometer for $\mathrm{RH}$. Both instruments used were from Cocet, China. All measurements were recorded inside and outside the vehicle at 1, 2, 3, 4, 5, and finally at $6 \mathrm{~h}$ during the journey.

\section{Blood analysis and egg production}

Blood samples $(0.5 \mathrm{ml})$ were obtained from the brachial vein by simple venopuncture of ten birds per group immediately prior to loading into the crate and upon removal. Blood smears were made for subsequent differential leukocyte analysis following May-Grunwald staining (Robertson and Maxwell, 1990) and $\mathrm{H} / \mathrm{L}$ ratios were calculated (Mitchell et al., 1992). Egg production was recorded daily for three days before and after the journey.

\section{Statistical analysis}

All data were subjected to the student's paired t-test. Data were expressed as mean \pm standard error of the mean $($ mean $\pm S E M)$. Values of $(p<0.05)$ were considered significant.

\section{RESULT}

The meteorological data before, during and after the journey throughout the study period are given in (Tables I, II and III). The AT, dry-bulb temperature (DBT) and RH before and after the journey did not show any significant $(p>0.05)$ range difference. However the maximum and minimum AT showed a consistent pattern of increase from 07:00 h, peaked at 14:00 $\mathrm{h}$, and then decreased at 18:00 $\mathrm{h}$ before and after the journey. The minimum AT recorded during the study period was $25.0^{\circ} \mathrm{C}$, while the maximum for the same period was $33.0{ }^{\circ} \mathrm{C}$. Similarly, the DBT inside and outside the pen throughout the experimental period showed a parabolic increase from 07:00 $\mathrm{h}$ to 18:00 $\mathrm{h}$, with a peak value at 14:00 h. The pre-transportation values of DBT inside the pen were consistently higher than the values recorded for outside, while reciprocal values were observed post-transportation. The overall mean

Table I

Meteorological data at the experimental site for three days before transportation of the SBL chickens.

\begin{tabular}{lcccccccc}
\hline & \multicolumn{2}{c}{$\begin{array}{c}\text { Ambient temperature } \\
\left({ }^{\circ} \mathrm{C}\right)\end{array}$} & \multicolumn{2}{c}{$\begin{array}{c}\text { Dry-bulb } \\
\left({ }^{\circ} \mathrm{C}, \text { Mean } \pm \mathrm{SEM}\right)\end{array}$} & \multicolumn{2}{c}{$\begin{array}{c}\text { Relative humidity } \\
(\%, \text { Mean } \pm \text { SEM })\end{array}$} & & \\
\cline { 2 - 6 } Hour & Maximum & Minimum & Outside Pen & Inside Pen & Outside Pen & Inside Pen & Rainfall (mm) & Wind Direction \\
\hline 07:00 & 26.0 & 25.0 & $25.3 \pm 1.7$ & $26.5 \pm 1.7$ & $97.3 \pm 3.3$ & $99.0 \pm 3.3$ & 0.0 & South - West \\
14:00 & 32.0 & 29.0 & $30.8 \pm 1.9$ & $30.7 \pm 1.9$ & $77.0 \pm 3.0$ & $81.7 \pm 3.0$ & 0.0 & South - West \\
$18: 00$ & 30.0 & 27.5 & $28.8 \pm 1.8$ & $31.2 \pm 1.9$ & $82.7 \pm 3.1$ & $92.0 \pm 3.2$ & 0.0 & South - West \\
Mean \pm SEM & $29.3 \pm 1.8$ & $27.2 \pm 1.2^{\mathrm{NS}}$ & $28.3 \pm 1.6$ & $29.4 \pm 1.5^{\mathrm{NS}}$ & $85.7 \pm 6.1$ & $91.2 \pm 5.3^{\mathrm{NS}}$ & $0.0 \pm 0.0$ & - \\
\hline
\end{tabular}

$\mathrm{SBL}=$ Shika Brown layer; $\mathrm{SEM}=$ Standard error of the mean; NS = Non-significant $(\mathrm{p}>0.05)$ difference.

Table II

Ambient temperature and relative humidity inside the vehicle during the journey period.

\begin{tabular}{ccc}
\hline Hour of Journey & Dry-bulb temperature $(\mathrm{oC})$ & Relative humidity $(\%)$ \\
\hline 1 & 32.0 & 67.0 \\
2 & 32.0 & 67.0 \\
3 & 34.0 & 62.0 \\
4 & 36.0 & 52.0 \\
5 & 36.0 & 48.0 \\
6 & 32.0 & 73.0 \\
Mean \pm SEM & $33.7 \pm 0.8$ & $61.5 \pm 3.9$ \\
\hline
\end{tabular}

$\mathrm{SEM}=$ Standard error of the mean. 
Table III

Meteorological data of the experimental site for three days post-transportation of the SBL chickens.

\begin{tabular}{|c|c|c|c|c|c|c|c|c|}
\hline \multirow[b]{2}{*}{ Hour } & \multicolumn{2}{|c|}{$\begin{array}{c}\text { Ambient temperature } \\
\left({ }^{\circ} \mathrm{C}\right)\end{array}$} & \multicolumn{2}{|c|}{$\begin{array}{c}\text { Dry-bulb } \\
\left({ }^{\circ} \mathrm{C}, \text { Mean } \pm \text { SEM }\right)\end{array}$} & \multicolumn{2}{|c|}{$\begin{array}{l}\text { Relative humidity } \\
(\%, \text { Mean } \pm \text { SEM })\end{array}$} & \multirow[b]{2}{*}{ Rainfall (mm) } & \multirow[b]{2}{*}{ Wind Direction } \\
\hline & Maximum & Minimum & Outside Pen & Inside Pen & Outside Pen & Inside Pen & & \\
\hline 07:00 & 26.0 & 25.0 & $25.7 \pm 0.2$ & $25.5 \pm 0.3$ & $94.7 \pm 2.7$ & $98.7 \pm 1.3$ & 0.0 & South - West \\
\hline $14: 00$ & 33.0 & 30.0 & $31.5 \pm 0.8$ & $30.7 \pm 0.4$ & $85.7 \pm 4.1$ & $91.7 \pm 3.8$ & 0.0 & South - West \\
\hline $18: 00$ & 30.0 & 28.5 & $29.7 \pm 0.3$ & $29.5 \pm 0.5$ & $80.0 \pm 5.0$ & $83.7 \pm 4.5$ & 0.0 & South - West \\
\hline Mean SEM & $29.7 \pm 2.0$ & $27.8 \pm 1.5 \mathrm{NS}$ & $29.0 \pm 1.7$ & $28.6 \pm 1.6 \mathrm{NS}$ & $86.8 \pm 4.3$ & $91.4 \pm 4.3 \mathrm{NS}$ & $0.0 \pm 0.0$ & - \\
\hline
\end{tabular}

$\mathrm{SBL}=$ Shika Brown layer; $\mathrm{SEM}=$ Standard error of the mean; NS = Non-significant $(\mathrm{p}>0.05)$ difference

DBT pre- and post-transportation followed the same pattern. The RH before and after the journey was higher inside the pen than outside and consistently decreased from 07:00 to 18:00 h. The overall pretransportation percentages $\mathrm{RH}$ inside and outside the pen were $91.2 \pm 5.3$ and $85.7 \pm 6.1$, while the values recorded post-transportation showed $91.4 \pm 4.3$ and $86.8 \pm 4.3$, respectively. During the journey, the DBT rose from $32.0{ }^{\circ} \mathrm{C}$ at the first hour and peaked at $36.0{ }^{\circ} \mathrm{C}$, corresponding to the fourth and fifth hour of the journey and 14:00-15:00 $\mathrm{h}$ of the day. A clear demonstration; that these were the hottest periods of the day in this region of the world. However, the $\mathrm{RH}$ showed a rise, fall and another increase at the first, fifth and sixth hours of the journey respectively. The lowest $\mathrm{RH}$ value of $48 \%$ was recorded at 15:00 $\mathrm{h}$, corresponding to the fifth hour and the hottest period of the journey, with a DBT of $36.0^{\circ} \mathrm{C}$. During this period, the birds were observed to be panting heavily. There was no rainfall during the study period, and wind direction was predominantly south-west.

Blood samples analyzed before and after transportation in control layers showed a decrease $(\mathrm{p}<0.05)$ in total white blood cell, $(\mathrm{p}<0.01)$ in lymphocyte and monocyte values, and a significant $(p<0.05)$ and $(p<0.001)$ increase in the values of eosinophils and heterophils post-transportation, respectively. In experimental groups, posttransportation values of total white blood cells, eosinophils and monocytes were not different ( $p>0.05)$ from those obtained pre-transportation. Heterophils/lymphocytes values were highest in the control group. The result showed that the transportation was stressful in control layers (Table IV).

\section{Table IV}

Total leukocyte and differential leukocyte counts in transported SBL chickens $(n=30)$ during the study period.

\begin{tabular}{|c|c|c|c|c|c|c|c|}
\hline Group & $\begin{array}{c}\text { WBC } \\
\left(\times 10^{3} \times / \mathrm{mm}^{3}\right)\end{array}$ & $\begin{array}{l}\text { Heterophils } \\
(\%)\end{array}$ & $\begin{array}{l}\text { Lymphocytes } \\
(\%)\end{array}$ & $\begin{array}{c}\text { Basophils } \\
(\%)\end{array}$ & $\begin{array}{c}\text { Eosinophils } \\
(\%)\end{array}$ & $\begin{array}{c}\text { Monocytes } \\
(\%)\end{array}$ & $\begin{array}{l}\mathrm{H} / \mathrm{L} \\
\text { ratio }\end{array}$ \\
\hline \multicolumn{8}{|l|}{ Before transportation } \\
\hline ++Vitamin C-treated & $3.8 \pm 0.1$ & $30.9 \pm 0.2$ & $55.6 \pm 0.6$ & $1.9 \pm 0.1$ & $1.9 \pm 0.0$ & $6.3 \pm 0.2$ & 0.56 \\
\hline++ Vitamin E-treated & $3.8 \pm 0.1$ & $30.1 \pm 0.3$ & $55.5 \pm 0.6$ & $1.9 \pm 0.1$ & $1.9 \pm 0.1$ & $6.4 \pm 0.2$ & 0.54 \\
\hline++ Control & $3.7 \pm 0.1$ & $30.9 \pm 0.3$ & $55.7 \pm 0.7$ & $1.9 \pm 0.1$ & $1.8 \pm 0.1$ & $6.3 \pm 0.2$ & 0.55 \\
\hline \multicolumn{8}{|l|}{ After Transportation } \\
\hline++ Vitamin C-treated & $3.7 \pm 0.1^{\mathrm{NS}}$ & $32.6 \pm 0.1^{*}$ & $53.8 \pm 0.2^{*}$ & $1.7 \pm 0.0^{\mathrm{NS}}$ & $2.0 \pm 0.0^{\mathrm{NS}}$ & $6.0 \pm 0.1^{\mathrm{NS}}$ & 0.61 \\
\hline++ Vitamin E-treated & $3.7 \pm 0.0^{\mathrm{NS}}$ & $33.5 \pm 0.2^{*}$ & $52.5 \pm 0.4^{*}$ & $1.7 \pm 0.0^{\mathrm{NS}}$ & $2.0 \pm 0.0^{\mathrm{NS}}$ & $6.2 \pm 0.2^{\mathrm{NS}}$ & 0.64 \\
\hline++ Control & $3.4 \pm 0.0^{*}$ & $40.9 \pm 0.2^{* * *}$ & $50.4 \pm 0.5^{\star *}$ & $1.8 \pm 0.0^{\mathrm{NS}}$ & $2.1 \pm 0.0^{*}$ & $4.8 \pm 0.1^{* *}$ & 0.81 \\
\hline
\end{tabular}

$\mathrm{SBL}=$ Shika Brown Layer; $\mathrm{WBC}=$ white blood cell; $\mathrm{H} / \mathrm{L}=$ Heterophil/Lymphocyte ratio, $\mathrm{PNSP}=$ Non-significant $(\mathrm{p}>0.05)$ difference; $*=$ $\mathrm{p}<0.05=$ Significant difference; ${ }^{* *}=\mathrm{p}<0.01=$ highly significant difference; ${ }^{* * *}=\mathrm{p}<0.001=$ Very highly significant difference; $++\mathrm{n}=10$ across the row.

Changes in egg production of SBL chickens in treated and control groups are given in (Table V). Three days post-transportation, the egg production of layer chickens administered with vitamins $C$ and
E were $49.0 \%$ and $70.0 \%$, while the control group was $32.3 \%$, respectively. The percentage decrease in egg production was calculated to be $40.5 \%$ for vitamin C, $13.6 \%$ for vitamin $\mathrm{E}$ and $59.6 \%$ for 
Table V

Number of eggs collected from SBL chickens $(n=90)$ three days before and three days after transportation.

\begin{tabular}{|c|c|c|c|c|c|c|}
\hline \multirow[b]{2}{*}{ Day } & \multicolumn{3}{|c|}{ Before Transportation } & \multicolumn{3}{|c|}{ After Transportation } \\
\hline & $\begin{array}{c}++ \text { Vitamin C } \\
\mathrm{N}(\% \text { Production })\end{array}$ & $\begin{array}{c}++ \text { Vitamin } \mathrm{E} \\
\mathrm{N}(\% \text { Production })\end{array}$ & $\begin{array}{c}++ \text { Control } \\
\mathrm{N}(\% \text { Production })\end{array}$ & $\begin{array}{c}++ \text { Vitamin C } \\
\mathrm{N}(\% \text { Production })\end{array}$ & $\begin{array}{c}++ \text { Vitamin E } \\
\text { N (\% Production })\end{array}$ & $\begin{array}{c}++ \text { Control } \\
\mathrm{N}(\% \text { Production })\end{array}$ \\
\hline 1 & $22.0(73.3)$ & $22.0(73 . .3)$ & $20.0(66.7)$ & $7.0(23.3)$ & $15.0(50.0)$ & $4.0(13.3)$ \\
\hline 2 & $26.0(86.7)$ & $26.0(86.7)$ & $25.0(83.3)$ & $15.0(50.0)$ & $22.0(73.3)$ & $10.0(33.3)$ \\
\hline 3 & $26.0(86.7)$ & $25.0(83.3)$ & $27.0(90.0)$ & $22.0(73.3)$ & $26.0(86.7)$ & $15.0(50.0)$ \\
\hline Mean \pm SEM & $\begin{array}{c}24.7 \pm 1.3 \\
(82.3)\end{array}$ & $\begin{array}{c}24.3 \pm 1.2 \\
(81.0)\end{array}$ & $\begin{array}{c}24.0 \pm 2.1 \\
(80.0)\end{array}$ & $\begin{array}{c}14.7 \pm 4.3^{*} \\
(49.0)\end{array}$ & $\begin{array}{c}21.0 \pm 3.2 \mathrm{NS} \\
(70.0)\end{array}$ & $\begin{array}{c}9.7 \pm 3.2^{* * *} \\
(32.3)\end{array}$ \\
\hline
\end{tabular}

$\mathrm{SBL}=$ Shika Brown layer; $\mathrm{NS}=$ Non-significant $(\mathrm{p}>0.05)$ difference; $*=\mathrm{P}<0.05 ; * * *=\mathrm{P}<0.001 ;++\mathrm{n}=30$ across the row .

control, compared to pre-transportation values. There was a highly significant $(p<0.001)$ and $(p<0.05)$ decrease in egg production in control and vitamin $C$ groups, while vitamin E group showed a non-significant $(\mathrm{p}>0.05)$ difference when compared to their pre-transportation values, respectively.

\section{DISCUSSION}

The results obtained in the present study showed that the transported chickens were subjected to the influence of high ambient temperature and high relative humidity, characteristic of the early rainy and late hot dry seasons in the Northern Guinea Savannah zone of Nigeria. The $27.2 \pm 1.2-29.3 \pm 1.8$ and $27.8 \pm 1.5-29.7 \pm 2.0{ }^{\circ} \mathrm{C}$ pre- and post-transportation AT values recorded were predominantly outside the established thermoneutral zone of $12-24{ }^{\circ} \mathrm{C}$ for birds reared in the temperate region (Selyansky, 1975), and 18$24^{\circ} \mathrm{C}$ for the tropical region (Holik, 2009). These results were also corroborated by the dry-bulb temperature values obtained inside and outside the pen throughout the study period. Similarly, the overall DBT value of $33.7 \pm 0.8^{\circ} \mathrm{C}$ recorded during the journey was very stressful for the birds, as evidenced by their heavy panting. The RH values recorded before and after the journey inside the pen, and more importantly during the journey were considerably high. Romijn and Lokhorst (1961) reported that the detrimental effects of high temperatures were more pronounced at higher $\mathrm{RH}$, while Balnave (2004), in a World Poultry Science Association (WPSA) invited lecture, concluded that high temperatures, accompanied by high humidity, is more detrimental to bird performance than high temperature with low humidity. The result of 33.7 ${ }^{\circ} \mathrm{C}$ DBT and $61.5 \% \mathrm{RH}$ during the journey in this study is in agreement with the findings of Mitchell and Kettlewell (1998), who employed a multidisciplinary approach in their study to characterize a microenvironment "thermal core" load in transported broiler chickens. The fundamental elements used to calculate apparent equivalent temperatures (AET) within the vehicle were DBT and RH. Results obtained from their study suggest that at heat loads associated with AET of 45 to 50 ${ }^{\circ} \mathrm{C}$, physiological stress would be minimal or mild. At values of AET between 50 and $70{ }^{\circ} \mathrm{C}$, moderate to severe and increasing physiological stress associated with failure of several homeostatic systems, tissue dysfunction and damage, metabolic derangements and activation of the hypothalamus pituitary axis (HPA) will be observed with increasing mortality. If AET reaches $90{ }^{\circ} \mathrm{C}$ or more, then extremely severe stress will occur with catastrophic failure of thermoregulation, profound hyperthermia, collapse and death in large numbers of birds in commercial practice. The authors concluded that the range of $\mathrm{RH}$ more commonly encountered in the thermal core is of the order of 70 to $80 \%$ and thus the onset of severe physiological stress may be expected at 25 to $26{ }^{\circ} \mathrm{C}$. This suggestion further demonstrates that transportation of layers during the early rainy season was thermally stressful to the layers. Such responses adversely affect health status and productivity of layers (West, 2003). Similarly, our results is in agreement with the findings of Igono et al (1982) and Ayo et al (1998) who reported that the hot-dry season is thermally stressful to animals. Furthermore, it has previously been predicted, on theoretical grounds, that increasing $\mathrm{RH}$ from 20 to $80 \%$ in a transport crate at a temperature of 28 ${ }^{\circ} \mathrm{C}$ would result in a thermal load upon the birds equivalent to an additional rate of rise in body temperature of $0.42{ }^{\circ} \mathrm{C} / \mathrm{h}$ (Mitchell et al., 1990). In the present study, rising $\mathrm{RH}$ at elevated temperature during the journey exerted marked effects on the degree of physiological stress experienced by the birds, as indicated by the increased physiological variable of $\mathrm{H} / \mathrm{L}$ and a decrease in egg production, especially in the control group. It has been documented that layer chickens show genetic variations especially in physiological response to 
transportation stress (Cheng and Jefferson, 2008). Indeed, the response observed in this study was negative in relation to the $\mathrm{H} / \mathrm{L}$ values recorded in the control group. This may be the result of exposure to high AT and RH as heat stress may occur if layers are subjected to high environmental temperatures due to high crating densities. Turner and Kettlewell (1983) noted that the density in the crates during transport is about twice that in the laying house. The high density in the crates makes it very difficult for the birds to dissipate their heat (Metheringham and Hubrecht, 1996). The increase in heterophils/ lymphocytes ratio due to heat stress is in agreement with studies of McFarlane and Curtis (1989), Huff et al (2005) and Minka and Ayo (2008). The H/L ratio has been used as a reliable indicator of stress in birds (Altan et al, 2000), indicating that, in our study, birds from the control group were significantly stressed compared to treated groups. Minka and Ayo (2008) found that layers supplemented with vitamin $\mathrm{C}$ and transported by road showed a significant $(p<0.05)$ increase in eosinophil, but a non-significant ( $p>0.05)$ difference in the numbers of basophils and monocytes. This result is in partial agreement with our findings; this may probably be due to the low dosage $(60 \mathrm{mg} / \mathrm{kg})$ to body weight administered in their experiment.

The significant decrease obtained in egg production in the control group compared to the treatment groups in this study confirmed the findings of Whitehead and Keller (2003), that vitamin E exerts both anti-stress and fertility effects on layer chickens. Similar findings on the positive effect of dietary supplementation of vitamins C and $\mathrm{E}$ in birds subjected to transport and heat stress were also reported by (Bollengier-Lee et al., 1998; Sahin et al., 2003a; Ciftci et al., 2005). In a separate report, Kazim et al. (2002) noted that dietary supplementation of vitamins $C$ and $E$ positively altered the negative process of serum lipid peroxidation observed in birds exposed to heat stress. They argued that the combination of these two vitamins offers a good management and hence layability at high temperatures. Furthermore, it has been well documented that dietary supplementation of vitamins $C$ and $E$ may alleviate the adverse effects of acute and chronic heat stress in laying hens, perhaps by maintaining the supply of egg precursors in plasma, while at the same time decreasing serum ACTH concentration (Sahin et al., 2002). Therefore, the results of the present study has further demonstrated that vitamin E administration to transported layer chickens at high ambient temperatures not only alleviated the adverse effects of road transportation stress, but also significantly reduced egg production losses unavoidably associated with road transportation stress in birds.
In conclusion, dietary supplementation of vitamin $\mathrm{C}$ and particularly vitamin $\mathrm{E}$ alleviated the adverse effects of heat stress in SBL chickens transported during the hot dry season. In addition, the results suggest that the combination of dietary vitamins $C$ and E could provoke possible synergistic effects on transported birds at high ambient temperatures.

\section{REFERENCES}

ALTAN O, PABUCCUOGLU A, ALTAN A, KONYALIOGLU S, BAYRAKTAR H (2003) Effect of heat stress on oxidative stress, lipid peroxidation and some stress parameters in broilers. Br Poult Sci 44: 545-550.

ALTAN O, ALTAN A, CABUK M, BAYRAKTAR H (2000) Effects of heat stress on some blood parameters in broilers. Turk J Vet Anim Sci 24: 145-148.

ANOKHIN BM, DANILEVSKY VM, ZANARIM LG (1991) Internal medicine on livestock. Moscow: Agropromizdat pp 339-352.

AYO JO, OLADELE SB (1996) Transport stress in food animals: A review. Nig Vet J special ed. 1: 58-68.

AYO JO, OLADELE SB, FAYOMI A, JUMBO SD, HAMBOLU JO (1998) Body temperature, respiration and heart rate in the Red Sokoto goat during the harmattan season. Bull Anim Hlth Prod in Afr 46: 161-166.

BALNAVE D (2004) Challenges of accurately defining the nutrient requirements of heat-stressed poultry. In: World's Poultry Science Association invited lecture. Poult Sci 83: 5-14.

BAYLISS PA, HINTON MH (1990) Transportation of broilers with special reference to mortality rates. Appl Anim Behav Sci 28: 93-118.

BEDANOVA I, VOSLAROVA E, VECEREK V, PISTEKOVA V CHLOUPEK P (2006) Effects of reduction in floor space during crating on haematological indices in broilers. Berl. Munch. Tierarztl Wochenschr 119: 17-21.

BOLLENGIER-LEE S, MITCHELL MA, UTOMO DB, WILLIAMS PEV, WHITEHEAD CC (1998) Influence of high dietary vitamin $\mathrm{E}$ supplementation on egg production and plasma characteristics in hens subjected to heat stress. $\mathrm{Br}$ Pol Sci 39: 106-112.

BOURAOUI R, LAHMAR M, MAJDOUB A, DJEMALI M, BELYEA R (2002) The relationship of temperaturehumidity index with milk production of dairy cows in a Mediterranean climate, Anim Res 51: 479-491.

CHENG HW, JEFFERSON L (2008) Different behavioral and physiological responses in two genetic lines of laying hens after transportation. Poult Sci 87: 885-892.

CIFTCI M, NIHAT ERTAS O, GULER T (2005) Effects of vitamin $\mathrm{E}$ and vitamin $\mathrm{C}$ dietary supplementation on egg production and egg quality of laying hens exposed to a chronic heat stress. Revue Med Vet 156: 107-11.

DAGHIR NJ (2009) Nutritional strategies to reduce heat stress in broilers and broiler breeders. Lohmann information 44 6-15.

DELEZIE E, SWENNEN Q, BUYSE J, DECUYPERE E (2007) The effect of feed withdrawal and crating density in transit on metabolism and meat quality of broilers at slaughter weight. Poult Sci 86: 1414-1423.

ELROM K (2000) Handling and transportation of broilers welfare, stress, fear and meat quality. Part II: Stress. Israel Vet Med Assoc 55: 1-12.

FALLENBERG MA, SPEISKY H (2006) Antioxidants: Their effects on broiler oxidative stress and its meat oxidative stability. World's Poult Sci J 62: 53-70.

FAZIO E, FERLAZZO A (2003) Evaluation of stress during transportation. Vet Res Comm 27: 519-524. 
FRANCO-JIMENEZ DJ, BECK MM (2007) Physiological changes to transient exposure to heat stress observed in laying hens. Poult Sci 86: 538-544.

HARTUNG J (2003) Effects of transport on health of farm animals. Vet Res Comm 27: 525-527.

HOLIK V (2009) Management of laying hens to minimize heat stress. Lohmann Information 44: 16-29.

HUFF GR, HUFF WE, BALOG JM, RATH NC, ANTHONY NB, NESTOR KE (2005) Stress response differences and disease susceptibility reflected by heterophil to lymphocyte ratio in Turkeys selected for increased body weight. Poult Sci 84 : 709-717.

IGONO MO, MOLOKWU ECI, ALIU YO (1982) Body temperature responses of Savannah Brown goats to the harmattan and hot-dry season. Intl J Biomet 26: 225-230.

KAZIM S, NURHAN S, SEMA Y (2002) Effects of vitamin C and vitamin $\mathrm{E}$ on lipid peroxidation, blood serum concentration of laying hens reared at high ambient temperature. Sci Med Publ 85: 35-45.

KNOWLES TG, BROOM DM (1990) The handling and transport of broilers and spent hens. Appl Anim Behav Sci 28: 75-91.

KOELKEBECK KW, CAIN JR (1984) Performance, behavior, plasma corticosterone, and economic returns of laying hens in several management alternatives. Poult Sci 63: 2123-2131.

LIN H, MERTENS K, KEMPS B, GOVAERTS T, DEKETELAERE B, DEBAERDEMAEKER J, DECUYPERE E, BUYSE J (2004) New approach of testing the effect of heat stress on egg quality: mechanical and material properties of eggshell and membrane. Br Poult Sci 45: 476-482.

MAURICE DV, LIGHTSEY SF, ABUDABOS A, TOLER JE (2002) Factors affecting ascorbic acid biosynthesis in chickens: III. Effect of dietary fluoride on L-gulonolactone Oxidase activity and tissue ascorbic acid (AsA) concentration. J Anim Physiol a Anim Nutr 86: 383-88.

MCFARLANE JM, CURTIS SE (1989) Multiple concurrent stressors in chicks. 3. Effects on plasma corticosterone and the heterophil:lymphocyte ratio. Poult Sci 68: 522-527.

METHERINGHAM J, HUBRECHT DR (1996) Poultry in transit A cause for concern? Br Vet J 152: 247-249.

MINKA NS, AYO JO (2008) Hematology and behavior of pullets transported by road and administered with ascorbic acid during the hot-dry season. Res Vet Sci 85: 389-393.

MITCHELL MA, KETTLEWELL PJ (1998) Physiological stress and welfare of broiler chickens in transit: Solutions not problems! Poult Sci 77: 1803-1814.

MITCHELL MA, KETTLEWELL PJ, MAXWELL MH (1992) Indicators of physiological stress in broiler chickens during road transportation. Anim Welfare 1: 91-103.

MITCHELL MA, KETTLEWELL PJ, ALDRED K, MEEHAN DA (1990) Characterisation of the broiler transport environment and associated physiological consequences. Appl Anim Behav Sci 26: 291-292.
NICOL CJ, SAVILLE-WEEKS C (1993) Poultry handling and transport. In: Livestock handling and transport. GRANDIN $\mathrm{T}$ (ed) Wallingford Oxon UK: CAB International pp 273-287.

RAMNATH V, REKHA PS, SUJATHA KS (2008) Amelioration of heat stress induced disturbances of antioxidant defense system in chicken by Brahma Rasayana. Evid- Based Compl Alt Med 5: 77-84.

ROBERTSON GW, MAXWELL MH (1990) Modified staining techniques for avian blood cells. Br Poult Sci 31: 881-886.

ROMIJN C, LOKHORST W (1961) Climate and poultry. Heat regulation in the fowl. Tijdschr Diergeneeskd 86: 153-172.

ROZENBOIM I, TAKO E, GAL-GARBER O, PROUDMAN JA, UNI Z (2007) The effect of heat stress on ovarian function of laying hens. Poult Sci 86: 1760-1765.

SAHIN K, SAHIN N, ONDERCI M, GURSU MF, MUSTAFA ISSI M (2003a) Vitamin C and E can alleviate negative effects of heat stress in Japanese quails. Food Agric Envir 1: 244-249.

SAHIN K, SAHIN N, YARALIOGLU S (2002) Effects of vitamin $\mathrm{C}$ and vitamin $\mathrm{E}$ on lipid peroxidation, blood serum metabolites and mineral concentrations of laying hens reared at high ambient temperature. Biol Trace Elem Res 85: 35-45.

SAHIN K, ONDERCI M, SAHIN N, GURSU MF, KUCUK O (2003b) Dietary vitamin C and folic acid supplementation ameliorates the detrimental effects of heat stress in Japanese quail. J Nutr 133: 1882-1886.

SELYANSKY VM (1975) Microclimate in poultry houses. Moscow: Kolos Publishing House pp 77-123.

SINKALU VO, AYO JO (2008) Diurnal fluctuations in rectal temperature of black Harco pullets administered with vitamins $\mathrm{A}$ and $\mathrm{C}$ during the hot-dry season. Int J Poult Sci 7: 1065-1070.

STERLING KG, BELL DD, PESTI GM, AGGREY SE (2003) Relationships among strain, performance, and environmental, temperature in commercial laying hens. J Appl Poult Res 12: 85-91.

ST-PIERRE NR, COBANOV B, SCHNITKEY G (2003) Economic losses from heat stress by US livestock industries. J Dairy Sci 86: 52-77.

TURNER MJB, KETTLEWELL PJ (1983) Modelling of heat stress in crated broiler chickens. Silsoe, Bedford, UK: Natl Inst Agric Eng DN/1201.

VECEREK V, GRBALOVA S, VOSLAROVA E, JANACKOVA B, MELENA M (2006) Effects of travel distance and the season of the year on death rates of broilers transported to poultry processing plants. Poult Sci 85: 1881-1884.

WARRISS PD, BEVIS EA, BROWN SN (1990) Time spent by broiler chickens in transit to processing plants. Vet Rec 127: 617-619.

WEST JW (2003) Effect of heat stress on production in dairy cattle. Am Dairy Sci Assoc 86: 2131-2144.

WHITEHEAD CC, KELLER T (2003) An update of ascorbic acid in poultry. World's Poult Sci J 59: 161-184. 
